\begin{tabular}{|c|c|c|c|}
\hline VERSITA & GOSPODARKA & SUROWCAMI & MINERALNYMI \\
\hline & Tom 28 & 2012 & Zeszyt 3 \\
\hline
\end{tabular}

\title{
Removal of magnesium from sphalerite concentrates by means of spent electrolyte deriving from the process of cathode zinc extraction
}

\begin{abstract}
Introduction
The domestic source of zinc and lead are deposits in dolomite rocks in the Silesia-Cracow region. Their economic utility is estimated at about 90.42 million tons of ores (Gawlik, Mokrzycki 2011). These ores contain an admixture of dolomite, which is an undesirable component in the process of zinc extraction trough hydrometallurgy. The content of magnesium amounts to as much as $2.5 \% \mathrm{MgO}$.

In practice, about $90 \%$ of magnesium included in zinc concentrates passes to the last production stage, i.e. to the electrolysis process of cathode zinc electrowinning from sulfate solutions. During the zinc electrodeposition process, magnesium accumulates in the circulating solutions. The increment of magnesium concentration in the electrolyte is one of the factors liable for a decline in zinc quality. The presence of this component in the electrolyte, especially in concentrations exceeding $17 \mathrm{~g} / \mathrm{dm}^{3}$, impairs the electrical conductance of the solution, affecting the technical and economic indexes. Because of the detrimental effect of electrolyte contaminations by magnesium, as well as other admixtures on the development of zinc electrodeposition, and since they affect the quality of cathode
\end{abstract}

* Dr hab. inż., Instytut Gospodarki Surowcami Mineralnymi PAN, Kraków; e-mail: ajar@min-pan.krakow.pl

** Dr., emeryt, Politechnika Krakowska, Kraków

*** Dr inż., **** Mgr inż., Politechnika Krakowska, Kraków 
zinc, a set magnesium limit concentration should be maintained during the process. In order to keep this limit concentration at the required level, a part of the electrolyte is removed from the electrolysis system.

One of the ways of decreasing the magnesium content in sphalerite concentrates is pre-leaching with sulfuric acid solutions (Sanak-Rydlewska, Małysa 1996; Małysa, Sanak-Rydlewska 1999).

The degree of removal of magnesium and other admixtures, and the rate of leaching are connected with the structure of the initial concentrate, its graining, the concentration of the applied sulfuric acid solution, etc. (Jarosiński, Fela 2005, 2007).

Quantitative analysis of this process allows the selection of optimum leaching parameters, as well as an optimum degree of purification of sphalerite concentrates from magnesium compounds. During chemical treatment of concentrates gypsum is formed. The presence of this phase in the concentrate is undesirable because it decreases the content of zinc and causes an increase in moisture and some distributions in the process of zinc winning. In order to remove gypsum after chemical treatment, the concentrates are floated.

The contaminations should be removed from the waste water generated during the chemical treatment of the concentrates. The relative low concentration magnesium and other components makes their recovery economically unfeasible.

No literature has been found regarding the decrease of magnesium from sphalerite concentrates by means of leaching with spent electrolyte derived from electrowinning of cathode zinc.

The subject of this paper is obtaining of low magnesium concentrates by means of chemical treatment and flotation using spent electrolyte from the zinc electrodeposition process as the leaching agent.

\section{Subject and method of investigations}

In the experiments, sphalerite concentrate was obtained during the selective flotation of zinc and lead ores. The samples were derived from the mechanical preparation department of a domestic zinc-lead plant. The chemical composition of the initial material is given in Table 1. The run of the research procedure is shown in Fig. 1.

In order to characterize the initial and final concentrates, X-ray investigations were carried out with the use of Philips diffractometer system X Pert and microscope observations (JEOL JSM 5400).

The main leaching experiments were conducted with $100 \mathrm{~g}$ of sphalerite concentrate samples and spent electrolyte. The pulp was stirred with a constant speed (80 rate/min) mechanical stirrer fitted with a stainless impeller. The solid/liquid mass ratio was 1:5. The removal of magnesium and other components was carried out for 1 hour at a temperature $20^{\circ} \mathrm{C}$. After completing the leaching, the contents of the reaction vessel were 
Content of some components in spent electrolyte

Zawartość poszczególnych składników w zużytym elektrolicie

\begin{tabular}{||l|c|c|c|c|c|c|c|}
\hline \multirow{2}{*}{\multicolumn{2}{c|}{ Kind of solution }} & \multicolumn{9}{c|}{ Content $\left[\mathrm{g} / \mathrm{dm}^{3}\right]$} \\
\cline { 2 - 9 } & $\mathrm{Zn}$ & $\mathrm{Mg}$ & $\mathrm{Mn}$ & $\mathrm{Pb}$ & $\mathrm{Fe}$ & $\mathrm{SO}_{4}$ & $\mathrm{Ca}$ \\
\hline \hline Recycled electrolyte & 120 & $<9$ & $1.0-2.3$ & traces & 0.01 & - & - \\
\hline Spent electrolyte (average ) & $30-60$ & $9-22$ & $0.5-4.0$ & 0.002 & 0.046 & 235.0 & - \\
\hline Spent electrolyte (used in tests) & 58.49 & 11.4 & 4.67 & 0.002 & 1.33 & 229.9 & 0.43 \\
\hline
\end{tabular}

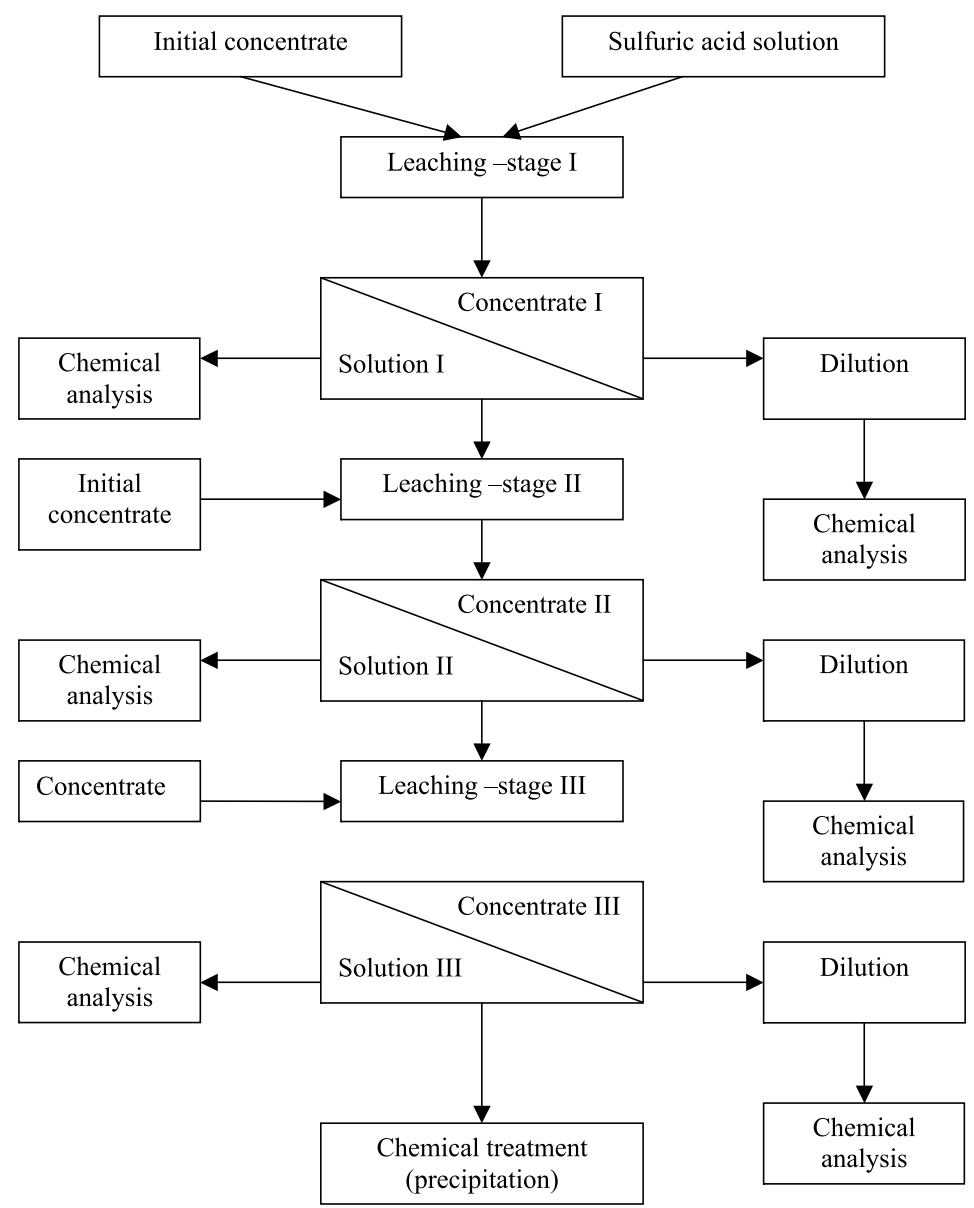

Fig. 1. The run of research procedure of magnesium removal on the way of chemical treatment

Rys. 1. Schemat postępowania podczas usuwania magnezu drogą chemiczną 
filtered. The solid residue after chemical treatment was dried and dissolved, then analyzed using the ICP method. The filtrates were also analyzed.

The flotation was performed in a $1.5 \mathrm{dm}^{3}$ laboratory flotation cell. The following reagents were used: sodium ethylxanthate $(\mathrm{EtXNa})$, copper sulfate and pine oil. The data listed are average values from at least three identical experiments.

\section{Results and discussion}

The mineral composition of the initial sphalerite concentrate is presented in Fig. 2.

In the tested samples, an essential component was sphalerite $-\mathrm{ZnS}$, while galena $-\mathrm{PbS}$, dolomite $-\mathrm{Ca}, \mathrm{Mg}\left(\mathrm{CO}_{3}\right)_{2}$ and calcite $-\mathrm{CaCO}_{3}$ appeared in meager amounts. Zinc can be observed as smithsonite $-\mathrm{ZnCO}_{3}$. Data from existing literature on the mineral phases of zinc and other elements are discordant. For example according Riesenkampf (Riesenkamf, Hamankiewicz 1981), a part of zinc is connected with dolomite - $\mathrm{Ca}(\mathrm{Mg}, \mathrm{Zn})\left(\mathrm{CO}_{3}\right)_{2}$. The presence of this mineral in zinc-lead ores results from the similarity of ionic radiuses: $\mathrm{Zn}^{2+}-7.4$ and $\mathrm{Mg}^{2+}-6.6 \mathrm{~nm}$.

SEM photograph of typical initial concentrate as used in this work is presented in Fig. 3.

The main mineral is sphalerite with a light, gray-white colour, the second sulfide mineral is galena, also appearing as a tint of light gray-white. Dolomite as a main mineral of gangue is

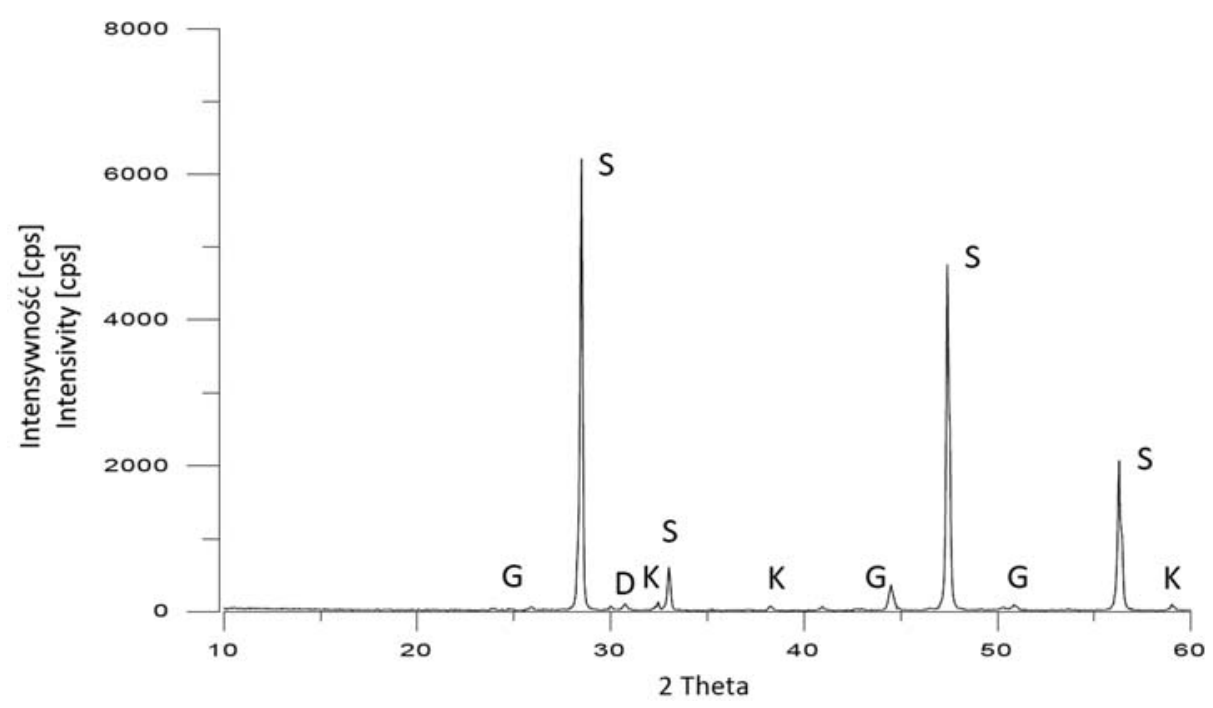

Fig. 2. X-ray diffraction of initial sphalerite concentrate used in research $\mathrm{S}$ - sphalerite, G - galena, D - dolomite, $\mathrm{K}$ - calcite

Rys. 2. Dyfraktogram koncentratu sfalerytowego przed oczyszczaniem S - sfaleryt, G - galena, D - dolomit, K - kalcyt 


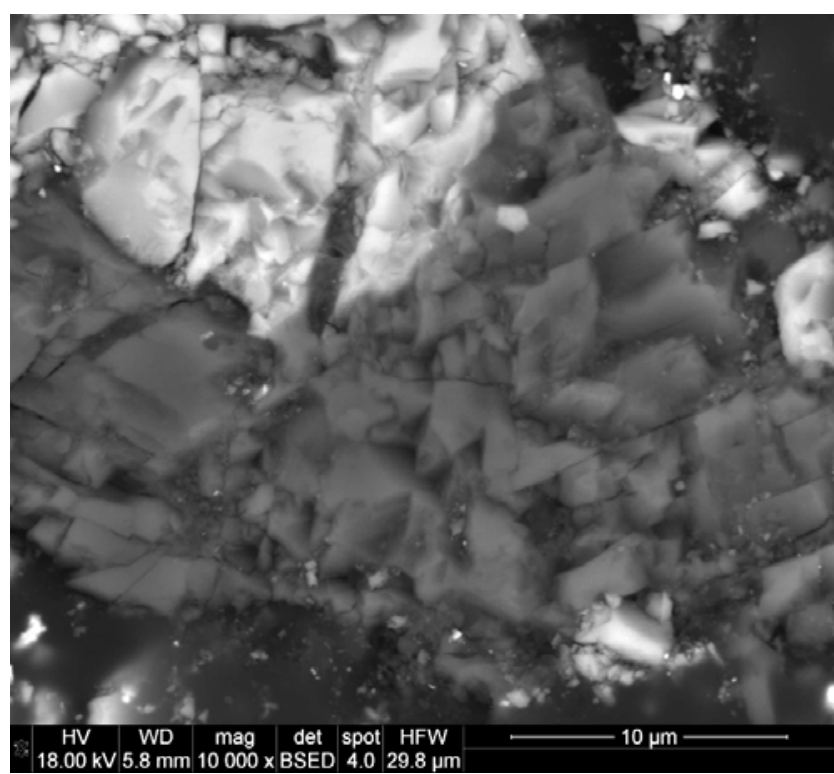

Fig. 3. SEM micrograph of the initial sphalerite concentrate

Rys. 3. Obraz SEM koncentratu sfalerytowego przed oczyszczaniem

visible in the form of darkened area of the use surface. This mineral occurs in the concentrate as free grains generally not more than $10 \mu \mathrm{m}$, and as intergrowths with sphalerite. Moreover, oxidative minerals in the from of smithsonite are observed.

In the first stage, the removal of magnesium from the initial concentrate on the chemical treatment was implemented. The results obtained were presented in Table 2.

TABLE 2

Leaching efficiency of some components from initial sphalerite concentrate in respective stages of chemical treatment

Efektywność ługowania poszczególnego składnika na każdym etapie z wyjściowego koncentratu sfalerytowego

\begin{tabular}{||c|c|c|c|c||}
\hline \multirow{2}{*}{ Stage of leaching } & \multicolumn{4}{|c||}{ Leaching efficiency [\%] } \\
\cline { 2 - 5 } & $\mathrm{Zn}$ & $\mathrm{Mg}$ & $\mathrm{Ca}$ & $\mathrm{Fe}$ \\
\hline \hline Stage I & 1.86 & 80.1 & 11.0 & 21.4 \\
\hline Stage II & 1.85 & 80.8 & 10.8 & 20.4 \\
\hline Stage III & 1.67 & 77.7 & 9.7 & 17.9 \\
\hline
\end{tabular}


48

Data indicates that losses of zinc during the selected chemical treatment were low. The composition of obtained solution and sphalerite concentrates after each stage of leaching is shown in Table 3.

TABLE 3

The composition of obtained solution and concentrates after each stage of leaching

TABELA 3

Skład roztworu i koncentratu na każdym etapie ługowania

\begin{tabular}{|c|c|c|c|c|c|c|c|}
\hline \multirow{2}{*}{$\begin{array}{c}\text { Com- } \\
\text { ponent }\end{array}$} & \multirow{2}{*}{$\begin{array}{c}\text { Con- } \\
\text { centrate }\end{array}$} & \multicolumn{2}{|c|}{ Stage I } & \multicolumn{2}{c|}{ Stage II } & \multicolumn{2}{c|}{ Stage III } \\
\cline { 2 - 8 } & solution I & concentrate I & solution II & concentrate II & solution III & concentrate III \\
\hline \hline \multirow{2}{*}{$\mathrm{Zn}$} & {$\left[\mathrm{g} / \mathrm{dm}^{3}\right]$} & 61.1 & - & 63.7 & - & 65.9 & - \\
\cline { 2 - 9 }$[\%]$ & - & 54.5 & - & 54.6 & - & 54.6 \\
\hline \multirow{2}{*}{$\mathrm{Mg}$} & {$\left[\mathrm{g} / \mathrm{dm}^{3}\right]$} & 14.1 & - & 16.7 & - & 19.3 & - \\
\cline { 2 - 9 } & {$[\%]$} & - & 0.2 & - & 0.25 & - & 0.40 \\
\hline \multirow{2}{*}{$\mathrm{Ca}$} & {$\left[\mathrm{g} / \mathrm{dm}^{3}\right]$} & 1.12 & - & 1.81 & - & 2.42 & - \\
\cline { 2 - 9 } & {$[\%]$} & - & 2.25 & - & 2.26 & - & 2.15 \\
\hline
\end{tabular}

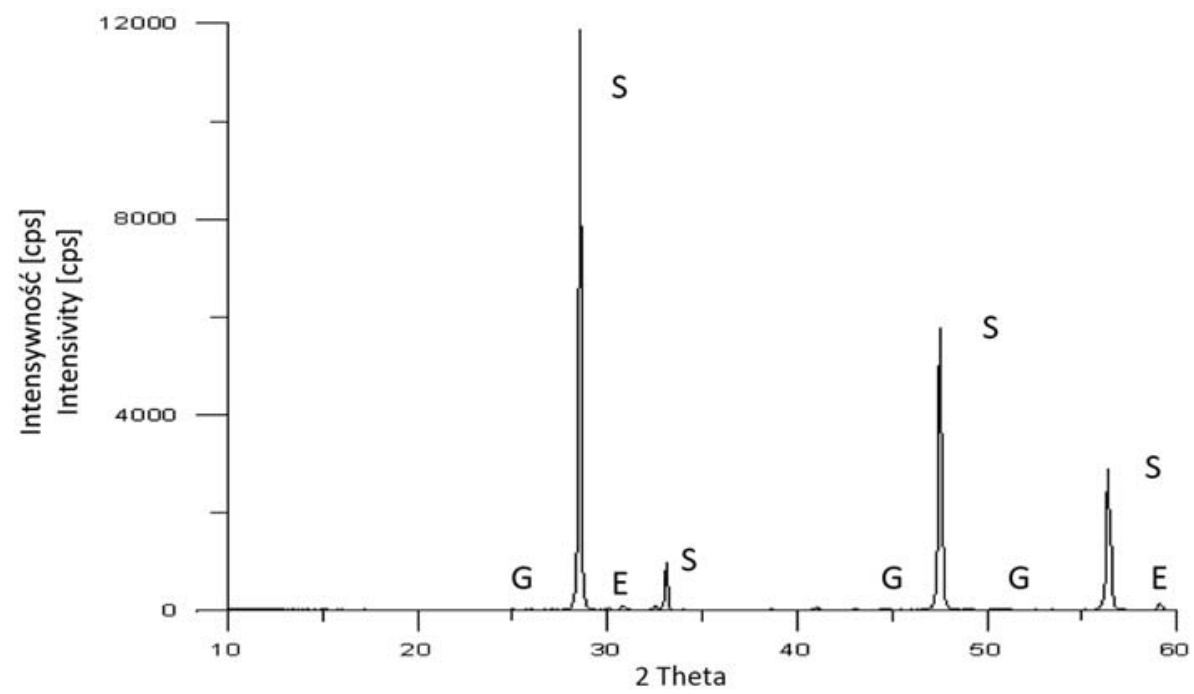

Fig. 4. X-ray diffraction pattern of the obtained concentrate after III stage of leaching $\mathrm{S}$ - spalerite, G - galena, E - gypsum

Rys. 4. Dyfraktogram koncentratu sfalerytowego po oczyszczaniu - ługowanie III $\mathrm{S}$ - faleryt, G - galena, E - gips 
Magnesium content in the obtained concentrates I and II were very low, which corresponds to technological requirements. In concentrate after III stage amounted to $0.4 \% \mathrm{Mg}$. In all concentrates content of main component decreased to $54.6 \% \mathrm{Zn}$. In all the obtained concentrates after leaching, the presence of gypsum is confirmed, for example, as in concentrate III (Fig. 4).

Therefore, in order to purify the concentrate from the gypsum phase, the flotation was used.

The effect of flotation on the removal of magnesium and calcium from the concentrate after the chemical treatment is presented in Fig. 5 and 6. The results confirmed that flotation

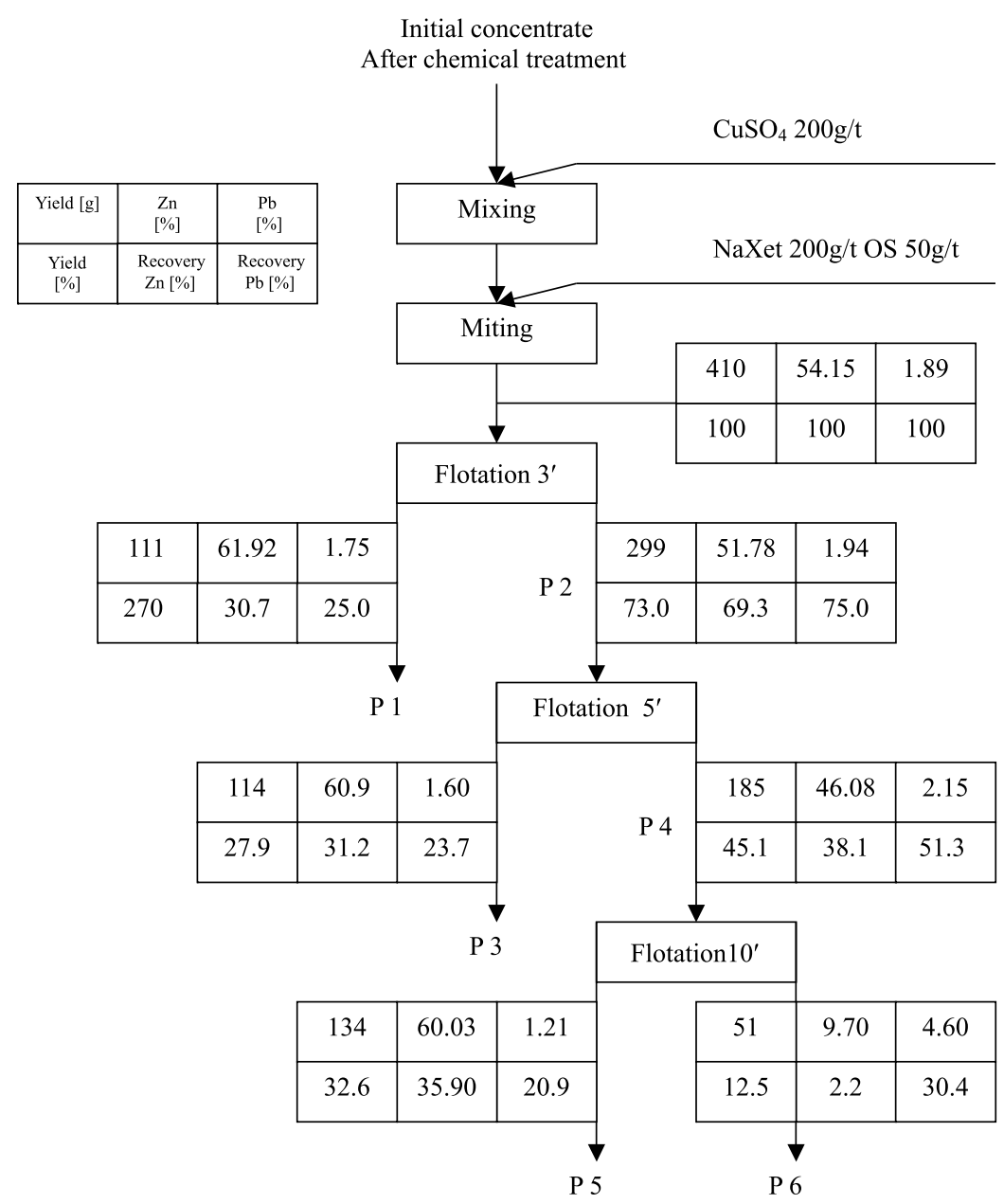

Fig. 5. Qualitative-quantitative flowsheet of sphalerite concentrate obtaing after chemical treatment for zinc and lead: leaching agent - spent electrolyte, time of leaching -1 hour

Rys. 5. Schemat ilościowo-jakościowy otrzymywania koncentratu sfalerytowego (cynk i ołów) po chemicznym oczyszczaniu: czynnik ługujący - zużyty elektrolit cynkowy, czas ługowania 1 godzina 


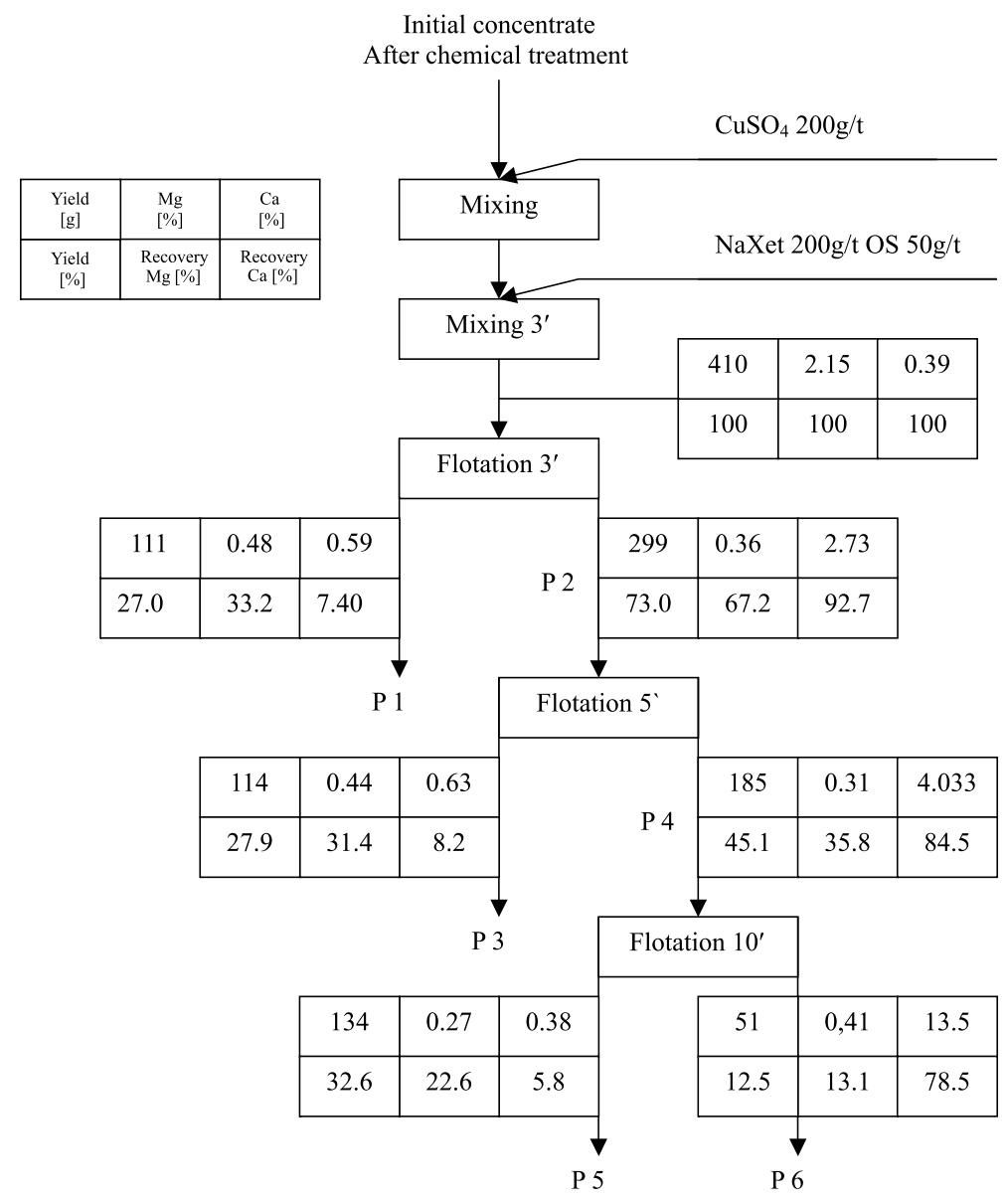

Fig. 6. Qualitative-quantitative flowsheet of sphalerite concentrate obtaing after chemical treatment for magnesium and calcium: leaching agent - spent electrolyte, time of leaching -1 hour

Rys. 6. Schemat ilościowo-jakościowy otrzymywania koncentratu sfalerytowego (magnez i wapń) po chemicznym oczyszczaniu: czynnik ługujący - zużyty elektrolit cynkowy, czas ługowania 1 godzina

was an efficient way of removing impurities from the concentrate after leaching such gypsum. In Fig. 7, curves of kinetics enrichment of zinc and lead by flotation are presented. Data indicates that recovery of zinc is high.

The phase examination of concentrate after chemical and flotation treatment of initial sphalerite concentrate confirmed in samples( $\mathrm{P} 1, \mathrm{P} 2)$ only sphalerite as the main phase, and only a small amount of galena (Fig. 8).

The results of flotation indicated that this means of gypsum elimination from concentrate was very efficient. These products can be numbered to high quality concentrates. 


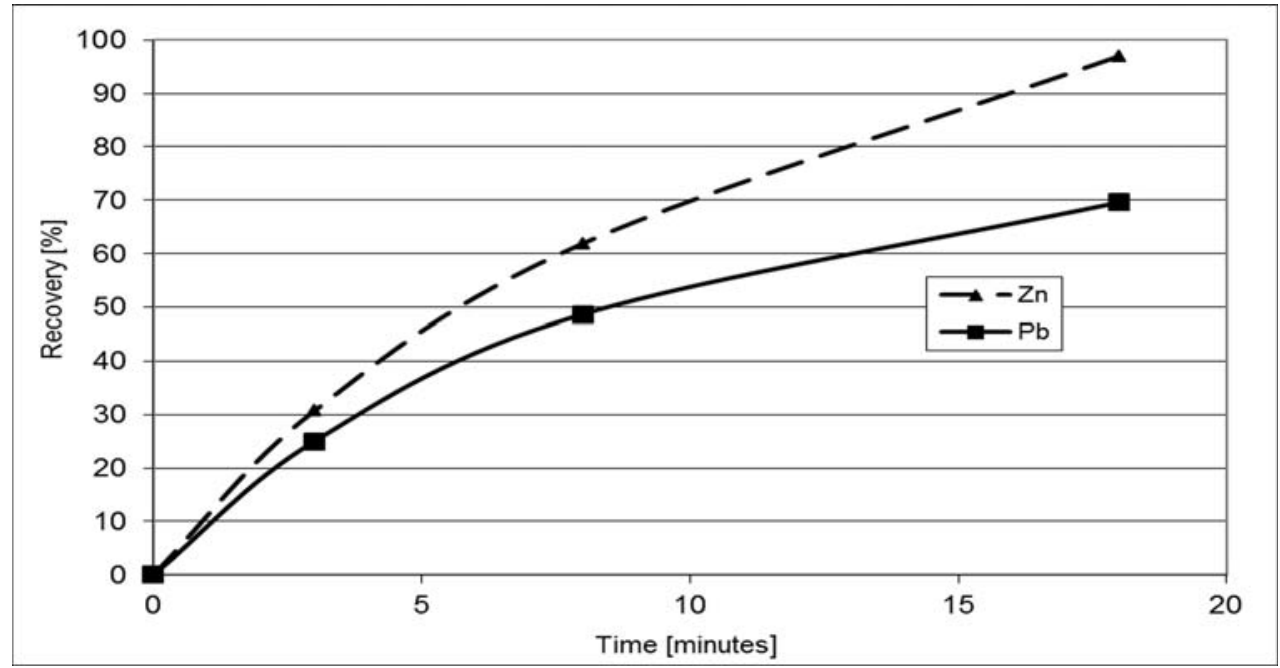

Fig. 7. Curves of kinetics enrichment of zinc and lead by flotation

Rys. 7. Krzywe kinetyczne wzbogacania cynku i ołowiu w czasie flotacji

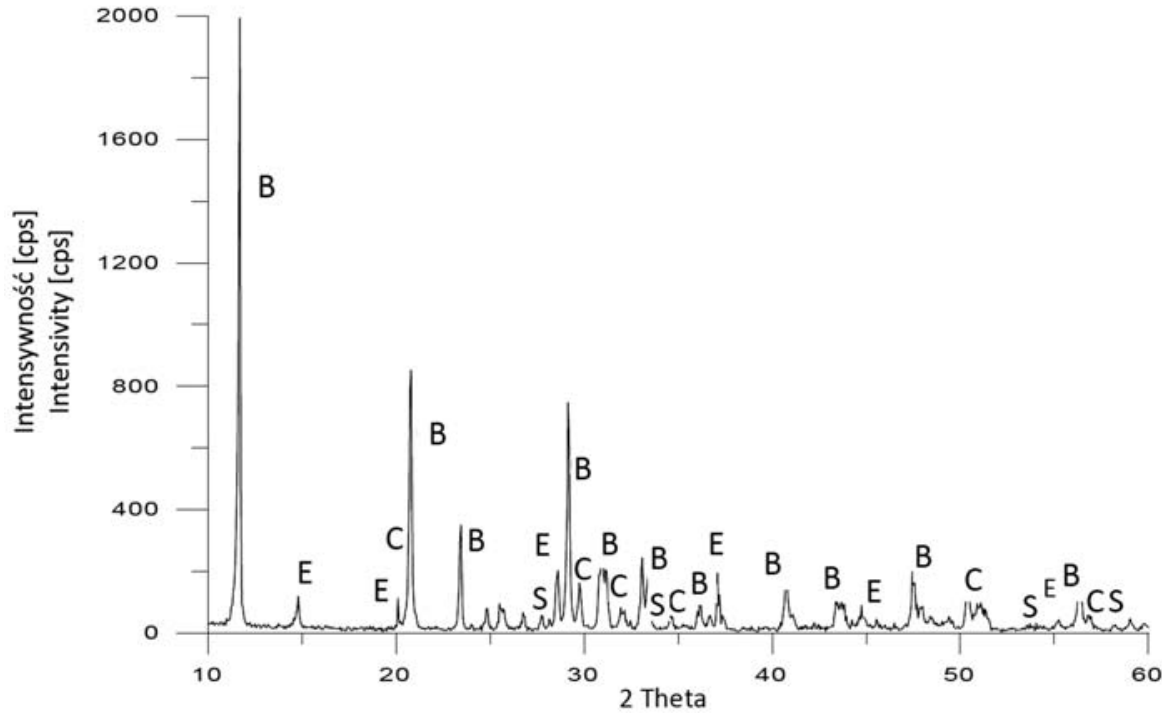

Fig. 8. X-ray diffraction pattern of the obtained concentrate after III stage of leaching $\mathrm{B}$ - spalerite, $\mathrm{C}$ - cerusite, E - gypsum

Rys. 8. Dyfraktogram koncentratu otrzymanego po III etapie ługowania B - sfaleryt, C - cerusyt, E - gips 


\section{Remarks}

The following conclusions can be drawn from this paper. The research of the sphalerite concentrate leaching process with spent electrolyte confirmed the usefulness of this method of magnesium removal. The leaching efficiency of magnesium for each stage of leaching was high amounting to over $77 \%$. Losses of zinc during the chemical treatment were low, which is beneficial for processing the recovery of zinc ores.

The solutions derived from each stage of chemical treatment characterize a high concentration of magnesium. This issue is a subject of separate studies.

The level of impurities ccontained in sphalerite concentrates obtained by means of chemical treatment, using sulphuric acid or spent electrolyte deriving from the zinc electrodeposition process as the leaching agent, as well as the cleaning flotation, is comparable.

\section{LITERATURA}

Gawlik L., Mokrzycki E., 2011 - Mineral Raw materials of Poland - Resource aspekt, Sustainable production and consumption of mineral resources. Wyd. IGSMiE PAN, Kraków, s. 13-39.

S a nak-Rydlewska S., Małys a E., 1996 - Purification of zinc blende concentrates by chemical flotation treatment to remove magnesium. Archieve of Metallurgy t. 41, s. 435-440.

Małys a E., S a nak-R y d lew ska S., 1999 - Application of chemical methods in processing of zinc-lead ores New trends in mineral processing III, Part II VSB-TU Ostrava, 24-26 Jule 1999, s. 367-373.

Jarosiński A., Fela K., 2007 - Application of sulphuric acid leaching for magnesium removal from zinc concentrate. Polish Journal of Chemical Technology t. 9, nr 2, s. 19-22.

Jarosiński A., Fela K., 2009 - The optimization of low-magnezium zinc concentrate production process. Polish Journal of Chemical Technology t. 1, s. 20-23.

Riesenkampf W., Hamankiewicz M., 1981 - Sposób występowania dolomitu w koncentracie flotacyjnym sfalerytu. Z zagadnień mineralogii stosowanej, Prace Mineralogiczne nr 70, Wyd. Geologiczne Warszawa.

Jarosiński A., 2009 - Badania nad usuwaniem magnezu z koncentratów cynku i utylizacją produktów ubocznych. Instytut Chemii i Technologii Nieorganicznej, Politechnika Krakowska, Kraków.

USUWANIE MAGNEZU Z KONCENTRATU SFALERYTOWEGO ZA POMOCĄ ZUŻYTEGO ELEKTROLITU Z PROCESU OTRZYMYWANIA CYNKU KATODOWEGO

\section{Słowa kluczowe}

Przeróbka rud cynku i ołowiu, usuwanie magnezu, koncentraty sfalerytowe

\section{Streszczenie}

Występowanie złóż rud cynku i ołowiu w skałach dolomitowych sprawia, że otrzymane koncentraty sfalerytowe zawierają domieszkę dolomitu. Praktyka wskazuje, że znaczna część wprowadzanego magnezu z surowcami cynkowymi przechodzi do ostatniej fazy produkcji, elektrolizy cynku. Obecność magnezu w elektrolicie 
obniża przewodnictwo elektryczne elektrolitu i powoduje pogorszenie wskaźników techniczno-ekonomicznych. Celem opisanych w tym artykule badań było opracowanie metody usuwania magnezu z surowego koncentratu sfalerytowego na drodze chemiczno-flotacyjnej, stosując zużyty elektrolit pochodzący z elektrolizy cynku. Opracowanie ukierunkowano wokół doświadczalnego zobrazowania istniejących zależności i ustalenia optymalnych warunków zaproponowanej procedury. Stopień wyługowania magnezu wynosił około $80 \%$. Straty cynku wynosiły poniżej $2 \%$, natomiast stężenie magnezu w roztworze wynosiło $20 \%$. Z tych roztworów można odzyskiwać magnez i cynk, co będzie przedstawione w następnej publikacji.

REMOVAL OF MAGNESIUM FROM SPHALERITE CONCENTRATES BY MEANS OF SPENT ELECTROLYTE DERIVING FROM THE PROCESS OF CATHODE ZINC EXTRACTION

$$
\text { Key words }
$$

Processing of zinc and lead ores, removal of magnesium, sphalerite concentrates

\section{Abstract}

Due to the occurrence of zinc and lead ore deposits in dolomite rocks, the sphalerite concentrates obtained from these ores contain an admixture of dolomite. In practice, a substantial amount of magnesium included in zinc ores passes to the last production stage, i.e. zinc electrolysis. The magnesium present in electrolyte impairs electrical conductance and appears in the technical and economical indexes. This paper deals the attempts to remove magnesium removal from initial sphalerite concentrates by means of chemical flotation using spent electrolyte derived from zinc electrolysis. The authors attempt to substantiate the existing relationships, as well as to derermine the optimum conditions for the procedure suggested. The leaching efficiency of magnesium amounted to about $80 \%$, and is dependent upon the stage of the leaching. Losses of zinc were below $2 \%$, and the magnesium concentration in solution amounted to about $20 \%$. These solution can produce magnesium and zinc, which will be presented in the following paper. 
